\title{
Sisis Hal: $189-202$ \\ EFFECT OF DISTRIBUTIVE JUSTICE ON THE RELATIONSHIP BETWEEN THE FORMS OF BENEFIT PROGRAM AND JOB COMMITMENT
}

\author{
Azman Ismail \& Chong Siaw Joon \\ Faculty of Cognitive Sciences \& Human Development \\ Universiti Malaysia \\ iazman@fcs.unimas.my
}

\begin{abstract}
This study was conducted to examine the moderating effect of distributive justice in the relationship between the forms of benefits program and job commitment. A survey research method was used to gather 150 usable questionnaires from employees who have worked in Malaysian federal government linked companies in Sarawak (MFGLS). The outcomes of testing moderating model using a hierarchical regression analysis showed two major findings: (1) distributive justice had not increased the effect of physical and safety benefits (i.e., health care, insurance, loan and claim) on job commitment, and (2) distributive justice had increased the effect of selfsatisfaction benefits (i.e., promotion opportunity and training) on job commitment. This result confirms that distributive justice does act as a partial moderating variable in the benefit program models of the organizational sector sample. In addition, the implications of this study to benefit system theory and practice, methodological and conceptual limitations, and directions for future research are also discussed.
\end{abstract}

Keywords: Forms of Benefits Program, Distributive Justice and Job Commitment

\section{INTRODUCTION}

Benefits program is a part of total compensation packages where it is also known as a non-monetary reward, non-cash payment and/or indirect payment. These terms are often used interchangeably in organizations, but it still refers to the same thing (Henderson, 2006; Milkovich \& Newman, 2007). In an organization perspective, an employer provides benefits program to all employees in order to complements monetary rewards, such as salary and bonus (Anthony, Perrewe \& Kacmar, 1996; Henderson, 2006). Benefits program can be divided in two major forms: firstly, physical and safety benefits (e.g., medical treatment, leave, loan and pension plans) and secondly, self-satisfaction benefits (e.g., promotion opportunity, training and flexible working hour) (Henderson, 2006; Hong, Yang, Wang, Chiou, Sun \& Huang, 1995). Traditionally, organizations provide such benefits to all employees based on membership and compliance with national laws. This perspective is based on a classical management approach where it retains employees through providing guaranteed non-monetary rewards, welfare, recreation and social based on job structure (e.g., position and seniority). In an era of global competition, the traditional paradigms of benefits program have been changed to support organizational strategy and goals. This new perspective is based on a contemporary management approach where it 
retains employees through rewarding extra benefits based on performance (Henderson, 2006; 1996; Milkovich \& Newman, 2007).

The design and implementation of performance based benefits reflect the responsiveness of an employer to dynamic changes that occur outside and inside its organization. Outside organizational factors are also called as internal alignment variables where it refers to corporate strategy, management philosophy, type of job and productivity level. Outside organizational factors are also known as external competitiveness variables, which refer to economic pressure, government policies, law and regulations, ownership, custom and practices. Organizations often use the outside and inside factors to design benefit structures and levels for employees who work in the various types of job (Arnault, Gordon, Joine \& Phillips, 2001; Henderson, 2006; Milkovich \& Newman, 2007). Many scholars think that the rules for distributing benefits based on performance and/or job will increase the capability of benefit packages to attract, retain and motivate high performers to support organizational strategy and goals (Henderson, 2006; Milkovich \& Newman, 2007).

Benefits management literature highlights that previous studies about compensation management have much described the internal dimensions of benefits system. For example, many discussions emphasize on concepts, purposes, forms, and rules of distributing benefits system, but effect of its program on individual attitudes and behaviors is not given more attention (Greenberg, 2003; Milkovich \& Newman, 2007). Recent studies in this area reveal that properly distributing the forms of benefits program to all employees may directly increase job commitment (Davis \& Ward, 1995; Skarlicki \& Folger, 1997). For example, the ability of an employer to determine the appropriate amount of physical and safety benefits (e.g., health treatments, leave, loan and pension) and increase the opportunity to gain selfsatisfaction benefits (e.g., promotion and training) may increase employee commitment (Fannin \& Fannin, 1983; Skarlicki \& Folger, 1997; Summer \& Miller, 2002). Surprisingly, a thorough investigation about such relationships reveals that effect of such benefit forms on job commitment does not clear if feelings of distributive justice are present in organizations. This relationship explains that properly allocating such physical and safety benefits, and self-satisfaction benefits to all employees based on job and/or performance will strongly invoke employees' feelings of distributive justice. As a result, it may lead to increased job commitment in organizations (Adams, 1963, 1965; Greenberg, 2003; Summer \& Miller, 2000). Although this issue has been studied, the moderating role of distributive justice in organizational benefits program is less emphasized (Adams' 1963, 1965; Milkovich \& Newman, 2007). Thus, it directs the researchers to further explore the nature of this relationship.

\section{LITERATURE REVIEW}

Physical and safety benefits, self-satisfaction benefits, distributive justice and job commitment are distinct constructs. Physical and safety benefits refer to 
health care, insurance, loan and claim (Henderson, 2006; Milkovich \& Newman, 2007). Physical and safety benefits refer to health care, insurance, loan and claim. Health care is provided to increase and maintain employees' well-being in terms of physiology and psychology (Bergmann \& Scarpello, 2002; Hong et al., 1995). Insurance is given to protect employee losses, damages, illnesses and/or death (Bergmann \& Scarpello, 2002; Henderson, 2006). Loan is allocated to enable an employee buys equipments and/or furniture (Bergmann \& Scarpello, 2002; Henderson, 2006). Claim is provided to an employee who does overtime jobs and/or outstation jobs (Henderson, 2006; Milkovich \& Newman, 2007). Conversely, self-satisfaction benefits are often related to promotion and training (Milkovich \& Newman, 2007). Promotion is provided to enable an employee holds higher positions will have opportunity to gain more rewards (McAdams, 1996;Morris, Arzmi \& Wood, 2004). Training is provided to enable an employee learning up-to-date knowledge, skills, competencies and good moral values that may increase his/her performance (Anthony et al., 1996; Longenecker \& Fink, 2005). Job commitment is a multi-dimensional construct where it consists of three major principles: affective, continuance and normative. These principles act as a glue that attaches individuals with an organization (Allen \& Meyer, 1990, Meyer, Allen \& Smith, 1993; Mowday, Porter \& Steers, 1982). Distributive justice refers to an individual perceives fairness about the type, level and/or amount of outcome (e.g., benefits) that he or she receives from his/her employer (Adams, 1963, 1965; McShane \& Von Glinow, 2003). Within a compensation system framework, many scholars think that the constructs are interrelated. For example, properly allocating the various forms of pay (e.g., benefits) will invoke employees' feelings of distributive justice, this may lead to increased job commitment (Adams, 1963, 1965; Milkovich \& Newman, 2007; Sweeney \& McFarlin, 1993).

In the MFGLS sector, HR managers and/or managers allocate benefits program based on the ability of organization to pay and national employment laws. Within the organizations, benefits program is determined to all employees based on broad policy and formal procedures set up by the organizations. For example, all employees are eligible to obtain health care, insurance, loan, claim, promotion and training. These benefits are given to complement monetary rewards (i.e., salary and bonus). Employees are eligible to gain the benefit forms based on two major criteria, i.e., job (position and seniority) and/or performance (contribution). Most employees feel that allocating these benefits based on such criteria may help them to fulfill basic necessities, decrease daily expenses and protect their welfares in the workplace. Thus, it may attract, retain and motivate good employees to support their strategies and goals. Although many studies have been done, the moderating role of distributive justice in the benefit program models of the organizations is less emphasized. Empirical evidence supporting the specific aspects of compensation system, especially benefits program is limited because of the paucity of research literature in this country (Azman, Yusof \& Sulaiman, 2007; Sulaiman \& Mamman, 1996). 
The moderating role of distributive justice in the benefits program of MFGLS is consistent with empirical studies mostly conducted in US organizational settings. For example, many studies about benefits program in US organizations show that properly distributing the forms of benefit program, such as health care, insurance, housing loan, work claims, promotion and training opportunities have invoked employees' feelings of distributive justice, this may lead to an enhanced job commitment (Davis \& Ward, 1995; Lipold, 2002; Morris, Arzmi \& Wood, 2004; Longenecker \& Fink, 2005). The empirical studies support the notion of Adams' $(1963,1965)$ equity theory, which explains that an individual often compares outputs (e.g. benefits) that he/she receives with inputs that he/she contributes (e.g. education, experience, skills and efforts) or compare his/her output-input ratio with other employees' output-input ratios. If an individual feels that benefits-contribution ratios are equitable, this will invoke his/her feeling of distributive justice about the benefits system. As a result, it may lead to increased job commitment.

Based on the above findings, it seems reasonable to assume that fairness of benefits forms will influence MFGLS employees as this feeling influences US employees. Adams' $(1963,1965)$ equity theory suggests that if MFGLS employees perceive fairness about the forms of benefits, this may lead to greater job commitment. Therefore, it was hypothesized that:

H1: Distributive justice positively moderates the effect of physical and safety benefits on job commitment.

H2: Distributive justice positively moderates the effect of self-satisfaction benefits on job commitment.

\section{RESEARCH METHODOLOGY}

Unit of analysis for this study was employees who have worked in three MFGLS. These companies have different core businesses, i.e., first company focuses on aviation, second company deals with mail and third company involves in telecommunication. As requested by the organizations, names of these companies were anonymous. Data for this study were gathered through three phases: in-depth interview, pilot study and actual survey. In-depth interviews were first conducted involving ten executives who have worked in the companies. Their opinions were sought to develop the contents of pilot survey questionnaire. After that, a pilot study was conducted to improve the contents and format of actual survey questionnaires. A back translation technique was used to translate the survey questionnaires in Malay and English languages in order to increase the validity and reliability of the research instrument (Hulland, 1999; Wright, 1996). The survey questionnaires had three sections. Firstly, benefit components, such as health treatment had 3 items, insurance had 4 items, loan had 4 items, claim had 4 items, promotion had 4 items, and training had 4 items that were modified from benefits management literature (Cole \& Flint, 2004; Haslinger \& Sheerin, 1994; Davis \& Ward, 1995; Henderson, 2006; Milkovich \& 
Newman, 2007). Secondly, distributive justice had 6 items that were modified from organizational justice literature (Adams, 1963, 1965; Greenberg, 2003; Skarlicki \& Folger, 1997). Finally, job commitment had 8 items that were modified from Mowday, Porter and Steers's job commitment scale (1979). The items used in the questionnaires were measured using a 7-item scale ranging from "strongly disagree/dissatisfied" (1) to "strongly agree/satisfied" (7). Demographic variables were used as controlling variables because this study focused on employee attitudes.

The unit analysis of this study is employees who have worked in MFGLS. Considering the constraints of the organization rules, a convenient sampling technique was used to gather data from the sample of this study. The 200 survey questionnaires were distributed to employees who work in every department through their supervisors/immediate bosses. Of the total number, 150 usable questionnaires were returned to the researchers, yielding 75 percent of the response rate. The survey questionnaires were answered by the participants based on their consents and a voluntarily basis. The number of this sample exceeds the minimum sample as required by inferential statistics (Leedy \& Ormrod, 2005; Sekaran, 2000). Therefore, a Statistical Package for Social Science version 14.0 was used to analyze the questionnaire data and thus test research hypotheses.

\section{RESEARCH FINDINGS}

Table 1 shows the sample profile. Majority respondents were male (59.3 percent), married employees (78.7 percent), employees had ages of 41 years old and above (47.3 percent), Malays (50.7 percent), Malaysian Certificate of Education holders (54.7 percent), working experienced more than 21 years (35.3), management staff (70.7 percent), and monthly salary ranged between RM2001-RM3000 (48.0 percent).

Table 2 shows that the survey questionnaires originally consist of 37 items, which related to eight variables: heath treatment (3 items), insurance (4 items), loan (4 items), claim (4 items), promotion (4 items), training (4 items), distributive justice (6 items), and job commitment (8 items). The results of reliability analysis showed that all variables had values of Cronbach Alpha of more than 0.63 , indicating it met the acceptable standard of reliability analysis (Nunally \& Bernstein, 1994). This analysis supports the notion of equity theories (Adams, 1963, 1965) and previous studies (Davis \& Ward, 1995; Lipold, 2002; Morris, Arzmi \& Wood, 2004; Longenecker \& Fink, 2005). 
Table 1: Participant Characteristics in the Organization

\begin{tabular}{|c|c|c|}
\hline Participant Characteristics & Sub-Profile & Percentage \\
\hline \multirow[t]{2}{*}{ Gender } & Male & 59.3 \\
\hline & Female & 40.7 \\
\hline \multirow[t]{3}{*}{ Marital Status } & Single & 20.7 \\
\hline & Married & 78.7 \\
\hline & Widow/ Widower & 0.7 \\
\hline \multirow[t]{6}{*}{ Age } & Less than 20 years old & 2.0 \\
\hline & $21-25$ years old & 8.7 \\
\hline & $26-30$ years old & 10.7 \\
\hline & $31-35$ years old & 13.3 \\
\hline & $36-40$ years old & 18.0 \\
\hline & More than 41 years old & 47.3 \\
\hline \multirow[t]{5}{*}{ Nationality } & Malays & 50.7 \\
\hline & Chinese & 12.0 \\
\hline & Indian & 2.0 \\
\hline & Native & 30.7 \\
\hline & Others & 4.7 \\
\hline \multirow[t]{7}{*}{ Education } & UPSR & 2.7 \\
\hline & PMR & 17.3 \\
\hline & SPM/SAP & 54.7 \\
\hline & STPM & 6.0 \\
\hline & Diploma & 11.3 \\
\hline & Degree & 8.0 \\
\hline & Others & 0 \\
\hline \multirow[t]{6}{*}{ Length of Service } & Less than 2 years & 12.7 \\
\hline & $3-5$ years & 13.3 \\
\hline & $6-10$ years & 8.0 \\
\hline & $11-15$ years & 8.0 \\
\hline & $16-20$ years & 22.7 \\
\hline & More than 21 years & 35.3 \\
\hline \multirow[t]{3}{*}{ Position } & Executive & 24.7 \\
\hline & Management Staff & 70.7 \\
\hline & Others & 4.7 \\
\hline \multirow[t]{5}{*}{ Salary (RM) } & Less than RM1000 & 13.3 \\
\hline & RM1001-RM2000 & 31.3 \\
\hline & RM2001-RM3000 & 48.0 \\
\hline & RM3001-RM4000 & 7.3 \\
\hline & More than RM4001 & 0 \\
\hline \multicolumn{2}{|l|}{ Note: } & $\mathrm{N}=150$ \\
\hline \multicolumn{3}{|c|}{ PMR: $\quad$ Lower Certificate of Education } \\
\hline \multicolumn{3}{|c|}{ SPM/SAP: Malaysia Certificate of Education and General Education Certificate } \\
\hline \multicolumn{3}{|c|}{ STPM: $\quad$ Higher School Certificate } \\
\hline
\end{tabular}


Table 2: Reliability Analysis

\begin{tabular}{lcc}
\hline \multicolumn{1}{c}{ Variable } & Items & Cronbach's Alpha \\
\hline Health Treatment & 3 & 0.78 \\
\hline Insurance & 4 & 0.88 \\
\hline Loan & 4 & 0.83 \\
\hline Promotion & 4 & 0.89 \\
\hline Training & 4 & 0.80 \\
\hline Claim & 4 & 0.84 \\
\hline Distributive Justice & 6 & 0.93 \\
\hline Job Commitment & 8 & 0.89 \\
\hline
\end{tabular}

Table 3 shows the results of descriptive statistics and Pearson correlation analysis. Means for all variables are between 4.69 and 5.47 ,, signifying the levels of health care, insurance, loan, claim, promotion opportunity, training opportunity, distributive justice and job commitment ranging from high (4) to highest (7). The correlation coefficients for the relationship between the independent variables (i.e., forms of benefit program) and the moderating variables (i.e., distributive justice) and the relationship between the independent variable (i.e., forms of benefit program) and dependent variable (i.e., job commitment) were less than 0.90 , indicating the data were not affected by serious colinearity problem (Hair, Anderson \& Tatham, 1998).

Table 3: Correlation Matrix Result for the Research Variable

\begin{tabular}{|c|c|c|c|c|c|c|c|c|c|c|}
\hline \multirow{2}{*}{ Variable } & \multirow{2}{*}{ Mean } & \multirow{2}{*}{ SD } & \multicolumn{8}{|c|}{ Pearson Correlation Analysis } \\
\hline & & & 1 & 2 & 3 & 4 & 5 & 6 & 7 & 8 \\
\hline Health Care & 5.47 & 0.94 & (1) & & & & & & & \\
\hline Insurance & 5.04 & 1.05 & $0.35^{\star *}$ & (1) & & & & & & \\
\hline Loan & 5.20 & 1.08 & $0.22^{* *}$ & $0.53^{* *}$ & (1) & & & & & \\
\hline Promotion & 4.69 & 1.26 & $0.27^{\star *}$ & $0.41^{* *}$ & $0.36^{\star *}$ & $(!)$ & & & & \\
\hline Training & 4.86 & 1.12 & $0.30^{\star *}$ & $0.45^{\star *}$ & $0.37^{* *}$ & $0.58^{* *}$ & (1) & & & \\
\hline Claim & 4.89 & 1.10 & $0.34^{* *}$ & $0.43^{* *}$ & $0.41^{* *}$ & $0.41^{* *}$ & $0.54^{* *}$ & (1) & & \\
\hline $\begin{array}{l}\text { Distributive } \\
\text { Justice }\end{array}$ & 5.04 & 1.01 & $0.23^{* *}$ & $0.26^{* *}$ & $0.30^{* *}$ & $0.30^{* *}$ & $0.27^{* *}$ & $0.35^{\star *}$ & (1) & \\
\hline $\begin{array}{l}\text { Job } \\
\text { Commitment }\end{array}$ & 5.80 & 0.60 & $0.28^{* *}$ & $0.26^{* *}$ & $0.17^{* *}$ & $0.41^{* *}$ & $0.30^{* *}$ & $0.31^{* *}$ & $0.38^{* *}$ & (1) \\
\hline
\end{tabular}

Note: ${ }^{* *}$ Correlation is significant at the 0.01 level (2-tailed) $\mathrm{SD}=$ Standard Deviation

Reliability estimation was shown in diagonal (1)

Pearson correlation analysis was unable to determine the moderator role of distributive justice in the hypothesized model. A moderated multiple regression analysis (as recommended by Cohen and Cohen, 1983) was used to test the moderating effect of distributive justice in the hypothesized model. Moderating effects are a type of interaction where the strength of relationship between an independent vari- 
able and a dependent variable is changed when other variables are present (Jaccard, Turrisi \& Wan, 1990; Kleinbaum, Kupper \& Miller, 1988). Proof of an interaction is evident when the relationship between interacting terms (i.e., product terms) and the dependent variable is significant. The fact that the significant main effects of predictor variables and moderator variables simultaneously exist in analysis does not affect the moderator hypothesis and it is significant to interpret the interaction term (Baron \& Kenny, 1986). The results of testing research hypotheses were shown in Table 4.

Table 4: Result for Multiple Regression Analysis with Distributive Justice as the Moderating Variable and Job Commitment as a Dependent Variable

\begin{tabular}{|c|c|c|c|}
\hline \multirow[t]{2}{*}{ Variable } & \multicolumn{3}{|c|}{ Dependent Variable } \\
\hline & Step 1 & Step 2 & Step 3 \\
\hline \multicolumn{4}{|l|}{ Controlled Variable } \\
\hline Gender & .073 & .083 & .059 \\
\hline Marital Status & .003 & .041 & .002 \\
\hline Age & -.098 & -.156 & -.146 \\
\hline Nationality & .030 & .010 & .021 \\
\hline Education Level & -.076 & -.089 & -.103 \\
\hline Length of Services & -.122 & -.103 & -.079 \\
\hline Position & -.047 & -.055 & -.062 \\
\hline Salary & .200 & .209 & .207 \\
\hline \multicolumn{4}{|l|}{ Independent Variable } \\
\hline Health Treatment & & .151 & .060 \\
\hline Insurance & & .054 & .519 \\
\hline Loan & & -.060 & -441 \\
\hline Promotion & & $.269^{* *}$ & $1.084^{* *}$ \\
\hline Training & & -.003 & -.763 \\
\hline Claim & & .074 & .123 \\
\hline Distributive Justice & & $.241^{* *}$ & .183 \\
\hline \multicolumn{4}{|l|}{ Moderating Variable } \\
\hline $\begin{array}{l}\text { Health Care } x \text { Distributive Jus- } \\
\text { tice }\end{array}$ & & & .166 \\
\hline Insurance $x$ Distributive Justice & & & -.604 \\
\hline Loan $x$ Distributive Justice & & & .517 \\
\hline Claim $x$ Distributive Justice & & & -.127 \\
\hline $\begin{array}{l}\text { Promotion x Distributive Jus- } \\
\text { tice }\end{array}$ & & & $-1.355^{* *}$ \\
\hline Training x Distributive Justice & & & $1.341^{*}$ \\
\hline R Square & .043 & .316 & .378 \\
\hline Adjusted R Square & -.011 & .239 & .276 \\
\hline R Square Change & .802 & $4.121^{* * *}$ & 3.703 \\
\hline $\mathrm{F}$ & .043 & .272 & .062 \\
\hline $\mathrm{F} \Delta \mathrm{R}$ Square & .082 & $7.613^{* * *}$ & 2.135 \\
\hline
\end{tabular}

Note: ${ }^{*} p<0.05 ;{ }^{* *} p<0.01 ;{ }^{* * *} p<0.001$ 
The regression analysis showed the outcomes of hypothesis testing. Firstly, interaction between distributive justice and physical and safety benefits (health care, $\beta=.166, p>0.05$; insurance, $\beta=-.604, p>0.05$; loan, $\beta=.517, p>0.05$; and claim, $\beta=-$ $.127, p>0.05$ ) insignificantly correlated with job commitment in Step 3, signifying that $\mathrm{H} 1$ was rejected. Secondly, interaction between distributive justice and selfsatisfaction benefits (promotion, $\beta=-1.355, p=0.01$; and training, $\beta=1.341, p<0.05$ ) significantly correlated with job commitment in Step 3 , showing that $\mathrm{H} 2$ was accepted. This result demonstrates that the strength of relationship between job commitment and self-satisfaction benefits has been affected when distributive justice included in the analysis, it sends a signal that distributive justice plays a moderating role in such relationships. While, the strength of relationship between job commitment and physical and safety benefits has not been affected when distributive justice included in the analysis, it sends a message that distributive justice does not play a moderating role in such relationships. In sum, this study confirms that distributive justice does act as a partial moderating variable in the benefits program models of the studied organizations.

\section{DISCUSSION, IMPLICATIONS, LIMITATIONS AND DIRECTIONS FOR FUTURE STUDY}

In MFGLS, management often determines the type, level and amount of benefits for their employees based on compensation policies and rules set up by the stakeholders. When employees perceive that they are provided adequate opportunities for promotion and training, this has invoked their feelings of distributive justice. As a result, it can lead to an increased job commitment in the workplace. Conversely, employees' feelings of justice about the physical and safety benefits have not motivated them to commit to the organizations. A thorough review of the in-depth interviews' results show external factors may overrule the moderating effect of distributive justice in the relationship between the physical and safety benefits and job commitment. The possible factors are: firstly, communication openness about benefits policies and procedures is rarely done between managers and employees, this will not help employees to understand the technical terms and conditions used in the benefit rules and regulations. As a result, may create misunderstanding and negative perceptions about the benefits program. Secondly, HR managers and/or managers are given major responsibilities to allocate benefits based on the standardized compensation policies and procedures set up by the stakeholders. In this situation, they have inadequate power and cannot use their judgments to change the procedures of allocating benefits in the organizations. In order to maintain reputation of the organizations, they prefer to treat employees' complaints and demands based on the rules and instructions from top management of the organizations.

The implications of this study can be divided into three categories: theoretical contribution, robustness of research methodology and practical contribution. In terms of theoretical contribution, this study has shown two major findings: firstly, indi- 
viduals' perceptions of justice about promotion opportunities strongly affect job commitment. This result is consistent with studies by Morris, Arzmi and Wood (2004). Secondly, individuals' perceptions of justice about training opportunities strongly affect job commitment. This result gains strong support from studies done by Longenecker \& Fink (2005). Conversely, individuals' perceptions of justice about physical and safety benefits (i.e., health care, insurance, loan and claim) have not increased job commitment. In sum, the findings of this study confirm that the notion of distributive justice has partially moderated the benefits program models of the organizational sector sample.

With respect to robustness of research methodology, the data gathered from compensation literature, the in-depth interviews and the survey questionnaires have exceeded a minimum standard of validity and reliability analyses, this can lead to the production of accurate and reliable findings. In terms of practical contributions, HR managers and/or managers may use the findings of this study to improve the administration of benefits program. For example, the type, level and/or amount of physical and safety benefits need to be given based on national cost of living. This may help majority employees to fulfill their basic needs and improve their standards of living. Besides that, the content and method for benefits training programs need to be customized according to organizational strategy and goals, this will help HR managers and/or managers to learn up-to-date knowledge, skills and competencies about interpersonal communication, counseling and problem solving skills. If this training program is properly implemented, this can lead HR managers and/or managers to provide better explanations about benefits program, and practice good treatments (e.g., show respect and accountability) when dealing with employees' complaints and demands. Thus, the paradigms of human resource planning need to be changed from hiring employees based on conforming the organizational policies to experienced and knowledgeable employees. Recruiting experienced and knowledgeable HR officers used in these will decrease training costs, and help organizations to design the various types of creative benefit plans (e.g., the value of rewards consistent with individual contributions), this may increase employee satisfaction and commitment with organization. If organizations heavily consider such suggestions, this will motivate positive attitudinal and behavioral outcomes. Hence, it may lead employees to support organizational and human resource management's strategies and goals.

The conclusions drawn from this study should consider the following limitations. Firstly, a cross-sectional research design used in this study did not capture the developmental issues or causal connections between variables of interest. Secondly, this study does not specify the relationship between specific indicators for the independent variable, moderating variable and dependent variable. Thirdly, the outcomes of multiple regression analysis have focused on the level of performance variation explained by the regression equations (Tabachnick \& Fidell, 2001), but there are still a number of unexplained factors that need to be incorporated to identify the causal relationship among variables and their relative explanatory power. Finally, the sample 
for this study was only taken from one three companies that allowed the researchers to gather data via in-depth interviews and survey questionnaires. The nature of this sample may decrease the ability of generalizing the results of this study to other organizational settings.

The conceptual and methodological limitations of this study should be considered when designing future research. Firstly, procedure justice as a moderating variable should also be included in future research model, this may provide meaningful perspectives for understanding on how it could affect job commitment (Folger \& Konovsky, 1989; Milkovich \& Newman, 2007). Secondly, longitudinal study may be used as an alternative research design to measure the effect of benefits program on individual attitudes and behaviors in future study. Finally, as described in recent compensation literature, other personal outcomes of distributive justice such as job performance, turnover and work ethics should be given more attention in future study because they may provide better perspectives in understanding effect of benefits program on many dimensions of work attitudes and behaviors (Folger \& Greenberg, 1985; Miceli \& Lane, 1991; Tremblay, Sire, \& Pelchat, 1998; Williams, 1995; Williams, Malos \& Palmer, 2002). The importance of this issues needs to be further explained in future research.

CONCLUSION

The study confirms that distributive justice does act as a partial moderating variable in the benefits program models of the studied organizations. This result has partially supported benefits program literature mostly published in US organizational settings. Therefore, current research and practice within the benefits program management needs to consider perceptions of distributive justice as a vital issue of the system. This study further suggests that benefits program should be properly designed based on the balancing between external and internal equity variables and administered based on justice principles. These practices will induce positive subsequent personal outcomes (e.g., satisfaction, performance, commitment, trust and good work ethics), thus may lead employees to support organizational and human resource management's strategies and goals.

\section{REFERENCES}

Adam, J.S. (1963). Toward an understanding of inequity. Journal of Abnormal and Social Psychology, 67, 422-436.

Adams, J.S. (1965). Inequity in social exchange. In Berkowitz, L. Advances in Experimental Social Psychology, 2, 267-299. New York: Academic Press.

Allen, N.J., \& Meyer, J.P. (1990). The measurement and antecedents of affective, continuance and normative commitment to the organization. Journal Occupational Psychology, 63, 1-18. 
Anthony, W.P., Perrewe, P.L., \& Kacmar, K.M. (1996). Strategic human resource management. New York: Harcourt Brace \& Company.

Arnault, E.J., Gordon, L., Joines, D.H. \& Phillips, G.M. (2001). An experimental study of job evaluation and comparable worth. Industrial and Labor Relations Review, 54 (4), 806-823.

Azman Ismail, Yusof Ismail \& Mohamad Sulaiman. (2007). Distributive justice, pay structure, and

attitudes and behavior: A Case of Malaysian Public Institutions of Higher Learning. This paper was published in the proceeding of the $4^{\text {th }}$ Academy of Global Business Advancement World Congress, May 21-25, 2007, Universiti Sains Malaysia and Academy for Global Business Advancement, Park Royal Hotel, Penang, Malaysia.

Baron, R.M. \& Kenny, D.A. (1986). The moderator-mediator variable distinction in social psychological research: Conceptual, strategic, and statistical considerations. Journal of Personality and Social Psychology, 51 (6), 1173-1182

Bergmann, T.J., \& Scarpello, V.G. (2002). Compensation decision making. Australia: South-Western Thomson Learning.

Cohen, J. \& Cohen, D. (1998). Applied multiple regression / correction analysis for the behavioural science. Hills Dale, NJ: Erlbaum.

Cole, N.D. \& Flint, D.H. (2004). Perceptions of distributive justice and procedural justice in employee benefits: Flexible versus traditional benefit plans. Journal of Managerial Psychology, 19 (1), 19-40.

Davis, E. \& Ward, E. (1995). Health benefits satisfaction in the public and private sectors: The role of distributive and procedural justice. Magazine: Public Personnel Management, 24(3), 255-270.

Fannin, T., \& Fannin, T. (1983). Coordination of benefits: Uncovering buried treasure. Personnel Journal. 386-91.

Folger, R., \& Greenberg, J. (1985). Procedural justice: An interpretive analysis of personnel systems. In Rowland, K., and Ferris, G. Research in Personnel and Human Resource Management, 3, 141-183.

Folger, R., \& Konovsky, M.A. (1989). Effects of procedural and distributive justice on reactions to pay raise decisions. Academy of Management Journal, 32, 115130.

Greenberg, J. (2003). Creating unfairness by mandating fair procedures: The hidden words of a pay-for-performance plan. Human Resource Management Review, 13, 41-57. 
Haslinger, J.A. \& Sheerin, D. (1994). Employee input: The key to successful benefits programs. Compensation and Benefits Review, 26 (3), 61-70.

Hair, J. F. Anderson, R.E., Tatham, R.L., \& Black, W.C. (1998) Multivariate data analysis. New Jersey: Prentice Hall International, Inc.

Henderson, R.I. (2000). Compensations management in a knowledge based-world. New Jersey: Prentice Hall.

Hong, J.C., Yang, S.D., Wang, L.F., Chiou, E.F., Sun, F.Y., \& Huang, T.L. (1995). Impact of employee benefits on work motivation and productivity. The International Journal of Career Management, 6: MCB University Press.

Hulland, J. (1999). Use of partial least square (PLS) in strategic management research: A review of four recent

studies. Strategic Management Journal, 20 (2), 195-204.

Jaccard, J., Turrisi, R. \& Wan, C.K. (1990). Interaction effects in multiple regression, 72. Newsbury Park, California: SAGE Publications, Inc.

Kleinbaum, D.G., Kupper, L.L. \& Muller, K.F. (1988). Applied regression analysis and other multivariable methods. Boston, Mass: PWS-Kent Publishing, Co.

Leedy, P.D., \& Ormrod, J.E. (2005). Practical research: Planning and design. Pearson Education Ltd.

Lipold, A.G. (2002). Benefit Integration Boosts Productivity and Profits. Workforce, $81,46-50$.

Longenecker, C.O., \& Fink, L.S. (2005). Management training: Benefits and lost Opportunities (part 1). Industrial and Commercial Training, 37 (1), 25-30.

McAdams, J.L. (1996). The reward plan advantage: A Manager's guide to Improving business performance through people. San Francisco: Jossey-Bass Publisher.

McShane, S.L. \& Von Glinow, M.A. (2005). Organization behavior. New York: McGraw Hill.

Meyer, J.P., Allen, N.J., \& Smith, C.A. (1993). Commitment to organizations and occupations: Extension and test of a three-component conceptualization. Journal of Applied Psychology, 78, 538-51.

Miceli, M.P., \& Lane, J.P. (1991). Antecedents of pay satisfaction: A review and extension. In Rowland, K.H., \& Ferris, G.R. Research in Personnel and Human Resource Management, 13, 235-309.

Milkovich, G. \& Newman, J.M. (2007). Compensation. Boston: Irwin McGraw-Hill. 
Morris, D. Arzmi, Y., \& Wood, G. (2004). Attitudes towards pay and promotion in the Malaysian higher educational sector. Employee Relations, 26 (2), 137-150.

Mowday, R.T., Porter, R.W., \& Steers, R.M. (1982). Employee organization linkages: The psychology of commitment, absenteeism and turnover. New York: Academic Press.

Mowday, R.T., Steers, R.M., \& Porter, L.W. (1979). The measurement of job commitment. Journal Vocational Behavior, 14, 224-247.

Nunally, J.C. \& Bernstein, I.H. (1994). Psychometric theory. New York: McGraw- Hill.

Sekaran, U. (2000). Research methods for business: A skill building approach. New York: John Wiley \& Sons, Inc.

Skarlicki, D. P., \& Folger, R. (1997). Retaliation in the workplace: The roles of distributive, procedural and interactional justice. Journal of Applied Psychology, 82, 434-443.

Sulaiman, M., \& Mamman, A. (1996). Managerial attitudes to pay system in the Malaysian public sector, Malaysian Management Review, 31 (1), 29-43.

Summer, T.P., \& Miller, J.L. (2000). Intra-and inter-justice relationships: Assessing the direction, Human Relations, 53 (10), 329-1347.

Sweeney, P.D., \& McFarlin, D.B. (1993). Workers' evaluation of the "ends" and the "means": An examination of four models of distributive and procedural justice. Organizational Behavior and Human Decision Processes, 55, 23-49

Tabachnick, B.G., \& Fidell, L.S. (2001). Using multivariate statistics. Sydney: Allyn \& Bacon.

Tremblay, M., Sire, B., \& Pelchat, A. (1998). A study of the determinants and of the impact of flexibility on employee benefit satisfaction. Human Relations, 51 (5),667-687.

Williams, M.L. (1995). Antecedents of employee benefit level satisfaction: A test of a model. Journal of Management, 21 (6), 1097-1128.

William, M.L., Malos, S.B., \& Palmer, D.K. (2002). Benefit system and benefit level satisfaction: An expanded model of antecedents and consequences. Journal of Management, 28 (2), 195-215.

Wright, L.L. (1996). Qualitative international management research. In Punnett, B.J., and Shenkar, O. Handbook for International Management Research, 63-81. Oxford, UK: Blackwell Publishers Inc. 